Mr James Pringle, who at the time of his death was Provost of Leith, received his education at the High School of Edinburgh, and was distinguished by his aptitude for classics. During his long connection with Leith he took a prominent part in promoting all its interests, and as chief magistrate rendered important services to the town.

Dr William Brown, who died in January last, was, I believe, the oldest member of this Society, having been admitted in 1835 . He had filled the office of President of the Royal College of Surgeons, and enjoyed a high reputation as a consulting physician.

Dr Rutherford Haldane, LL.D., was one of the most respected members of the medical profession in Edinburgh. After leaving our University he went abroad, for further study, to Vienna and Paris, spending eighteen months in the French capital. He became successively a lecturer on Pathology and on the Practice of Medicine in the Extra-Mural School. By his professional brethren he was regarded as an authority on all medical questions. He was a man of great learning; and his early death cannot fail to be much regretted by the Society.

The Rev. Francis Le Grix White, although, from residence at a distance from Edinburgh, personally but little known to many of us, kept up correspondence with the Society, was a man of varied accomplishments, and took an active part in organising scientific lectures in Cumberland and Westmoreland. He also promoted everything which tended to elevate those classes over whom his influence extended.

It only now remains for me to acknowledge the valuable help which I have received in the preparation of these notes from our friend $\mathrm{Mr}$ Gordon.

\title{
16. Minute of Meeting of Special Committee on the Victoria Jubilee Prize, 27th June 1887.
}

Victoria Jubilex Prize, founded by Dr Gunning of Rio Janeiro.

This Prize, founded in 1887, consisting of the interest of $£ 1000$, is to be awarded triennially by the Council of the Royal Society of Edinburgh. 
The Prize is to be given in recognition of original work in Physics, Chemistry, or Pure or Applied Mathematics.

Evidence of such work may be afforded either by a paper presented to the Society, or by a paper on one of the above subjects or some discovery in them elsewhere communicated or made, which the Council may consider to be deserving of the Prize.

The Prize is open to men of science resident in, or connected with Scotland.

The first award shall be in the year 1887, and shall consist of a sum of money. In accordance with the wish of the donor, the Council of the Society may on fit occasion award the Prize for work of a definite kind to be undertaken during the succeeding three years by a scientific man of recognised ability.

Before entering on the last of the subjects of this evening's meeting, it will interest you to learn that, heartily joining as we all do in the loyal and affectionate homage of the whole nation on the completion by the Queen of the 50th year of her happy and beneficent reign, the following Address has been forwarded to the Secretary of State for presentation, the arrangements not permitting its presentation by our President:-

"Madam, may it please your Majesty,-We, the President and Council of the Royal Society of Edinburgh, humbly address your Majesty on this, the 50th anniversary of your Majesty's illustrious reign, and desire to express, on behalf of the Society, their loyal attachment to your Majesty, and to the institution of the Crown, represented in the person of our present gracious and distinguished Sovereign.

"The Royal Society of Edinburgh was constituted in the year 1782, for the promotion of scientific and literary research, by a Charter from King George the Third. In times past it has counted amongst its members many statesmen, and men of letters and science, who have discussed freely the public and political questions of the times. But on one subject there has happily been entire unanimity-the maintenance of the principle of constitutional monarchy as established in the British Empire under the guidance of your Majesty and your Royal predecessors. 
"We are deeply sensible of the advantages which we have derived, during the past fifty years of social and legislative progress, from the presence, at the head of the affairs of this great Empire, of a Sovereign who is dissociated from the contentions of political parties, and is possessed of those high personal qualities which enable the Crown to exert a moderating and controlling influence in the public life of the country.

"As a Scottish Society, we claim a share in the sentiments of pride and loyal attachment which your Majesty's personal relations with Scotland have evoked in the hearts of our fellow-countrymen. We trust that your Majesty may long continue to derive health and solace from annual visits to your Majesty's Highland home; and we at the same time regard your Majesty's gracious presence amongst us as a guarantee of that interest in, and knowledge of our distinctively national affairs, which, as Scotsmen, we most highly value.

"In addressing the Royal Successor of the ancient Scottish Sovereigns, who in troubled times ruled this country with courage and ability, we may conclude by offering to your Majesty our most respectful and loyal congratulations on the good fortune, peace, and prosperity which have hitherto accompanied your Majesty's brilliant and eventful reign; and by expressing the hope that the interests of science and learning, with which this Society is connected, and whose marvellous development has been one of the characteristic features of that reign, may continue to flourish, as heretofore, under your Majesty's gracious encouragement and protection.

Signed on behalf of the Council of the Royal Society of Edinburgh.

Williay Thomson, President.

June 1887. 